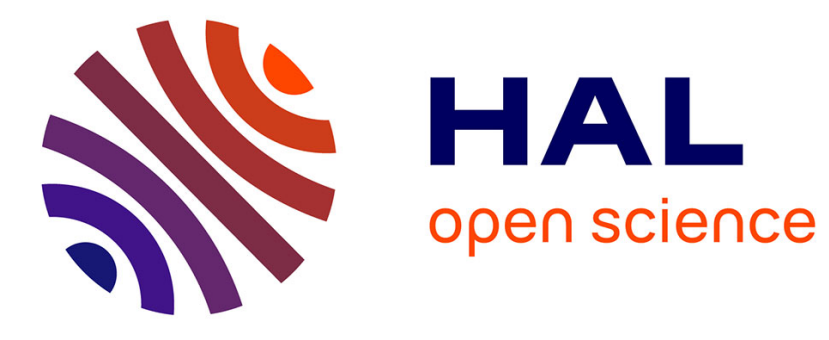

\title{
Henri Lefebvre's rhythmanalysis as a form of urban poetics
}

Claire Revol

\section{To cite this version:}

Claire Revol. Henri Lefebvre's rhythmanalysis as a form of urban poetics. Leary and Mc Carthy. The Routledge Handbook of Henri Lefebvre, the City and Urban Society, Routledge, 2019. halshs02010529

\section{HAL Id: halshs-02010529 \\ https://shs.hal.science/halshs-02010529}

Submitted on 7 Feb 2019

HAL is a multi-disciplinary open access archive for the deposit and dissemination of scientific research documents, whether they are published or not. The documents may come from teaching and research institutions in France or abroad, or from public or private research centers.
L'archive ouverte pluridisciplinaire HAL, est destinée au dépôt et à la diffusion de documents scientifiques de niveau recherche, publiés ou non, émanant des établissements d'enseignement et de recherche français ou étrangers, des laboratoires publics ou privés. 


\title{
Chapter Number XX
}

\section{Henri Lefebvre's Rhythmanalysis as a form of Urban Poetics}

\author{
Ms. Claire Revol
}

\begin{abstract}
Summary
Lefebvre's texts on rhythmanalysis are open to a variety of readings. By placing rhythmanalysis in the broader context of Lefebvre's work, the rhythmanalytical project emerges as what I have argued to be an urban poetics. A progressive reading of the different texts Lefebvre wrote on rhythmanalysis shows that, beyond rhythmanalysis' contribution to the critical theory of urban space and time, the imagination becomes an alternative for the creation of time-spaces in the form of experimental utopias and the creation of lifestyles. Rhythmanalysis can then be understood as a general quest for the appropriation of time and space in the renewal of the possibility of the urban to become a human oeuvre. This chapter will outline the development of Lefebvrian urban poetics through the rhythmanalytical project.
\end{abstract}




\section{Introduction}

At first sight, it is difficult to define the boundaries of the rhythmanalytical project and demonstrate precisely how it is related to Lefebvre's critical theory, notably in terms of the conceptual framework that he developed for urban planning and the production of space in general. Lefebvre did not detail the full implications of what remained a 'project', nor did he reveal the 'elements' of his 'secret garden', as his friend and colleague, Rene Lourau, who posthumously published Lefebvre's unfinished writings as Éléments de rythmanalyse (Lefebvre 1992, 2004) would later describe it. Texts mentioning the rhythmanalytical project have been written over a long period of time and have been redefined according to evolutions in Lefebvre's thinking. In the second Critique of everyday life (Lefebvre 1961), inspired by Bachelard's book written in 1936 The dialectic of duration (Bachelard 1950), Lefebvre first mentions it as an approach to studying social time. He then alludes to it in The production of space (Lefebvre 1974), Towards an architecture of enjoyment written in 1973 (Lefebvre 2014) and his writings on music, before finally describing it as a consistent project in the third Critique of everyday life (Lefebvre 1981) as well as the articles 'The rhythmanalytical project' in 1985 (Lefebvre 2004) and an 'Attempt at the Rhythmanalysis of Mediterranean Cities' in 1986 (Lefebvre 2004).

Elements of Rhythmanalysis: An introduction to the Understanding of Rhythms (Lefebvre 1992; 2004) is a collection of chapters that provides no linear argumentation for the reader. It is rather a collection of fragments, a series of 'preludes', to appropriate Lefebvre's description of the structure of 
his book, Introduction to modernity (Lefebvre 1962). It is hard to believe that these writings were unfinished because of the lack of time. Lefebvre is a prolific author. He has written more than sixty books, some of them in but a few months. As opposed to Introduction to modernity, Elements of Rhythmanalysis is written in a lapidary way, with most of the terms referring to Lefebvrian concepts without any form of explanation. If we consider these texts to be a general view, or a synthetic picture of the rhythmanalytical quest- which could explain why some of the terms are written in bold or italic letters - we are still without an explanation of their status in his critical theory. Curiously, even though Lefebvre grounds his theory of rhythms in aesthetics, he rarely refers either to space or the urban question. If the Elements of Rhythmanalysis is an 'introduction' to the knowledge of rhythms, how do we then complete it without overinterpreting it?

I shall seek to establish how rhythmanalysis fits into the general framework of lefebvrian theory through an exploration of the particular texts in which he refers to the rhythmanalytical project. I assume that Lefebvrian critical theory unfolds along the lines of his development of a 'poetics' and that the rhythmanalytical project, which borrows its intuitions from Bachelard's poetics, can be read as a contribution to urban poetics. I have developed this point of view in my doctoral thesis in philosophy, Henri Lefebvre's Rhytmanalysis as a form of Urban Poetics (Revol 2015).

Lefebvre develops rhythmanalysis by means of his contact with artistic practices, especially those of the Situationist International. Against his critique of abstraction as the inherent process of urban space and time, 
Lefebvre proposes rhythmanalysis as a way to construct an appropriate space-time, including the ability to transform urban society and reconfigure the 'total body' so that the urban can instead be considered as a work of art. Lefebvre thus provides more than a qualitative methodology for the observation of rhythms, he outlines a rhythmanalytic experimentation that can be associated with the practices of an experimental utopia.

Rhythmanalysis therefore offers the guidelines for an applied poetics; it goes as far as creating forms, textures and styles for urban living. This urban poetics, as a creative act steeped in knowledge, proceeds through experimentation; it restores the rhythmic game that enriches our aesthetic experience of urban space and time.

Thus Lefebvre's writings on space and time should not be considered as a purely social theory, but rather as an integral part of urban poetics. Lefebvre developed the anthropological dimension of his poetics in his book Métaphilosophie (Lefebvre 1965b), that I will analyse as a combination of his writings on social theory and urban poetics.

\section{Rhythmanalysis and the social production of space-time}

The point of departure for the rhythmanalytical project can be found in the second volume of the Critique of everyday life - Foundations for a Sociology of the Everyday (Lefebvre 1961), in which Lefebvre defines his sociology as a radical and critical theory.

The critique of everyday life that Lefebvre explores is rooted in his project 
of structuring a critical knowledge of modern man and the modern world through his reading of Marx's first texts and his understanding of alienation. He developed this particular theorization of dialectical materialism in the 1930s with Norbert Guterman, notably in the introduction to Lenin's Hegel Notebooks, (Lefebvre and Guterman 1935), The Mystified Consciousness (Lefebvre and Guterman 1936) and Dialectical Materialism (Lefebvre 1939b). The main thesis is that the banality of ideas in the functioning of daily society makes awareness of alienation difficult. Critical theory must study forms of consciousness in human practices (ideas, institutions, cultures) as concrete forms of the lifestyles and existence of human beings (Lefebvre 1939b: 67). Thus critical theory is a theory of praxis that dialectically exposes the production of ideas and things (Lefebvre 1935: 178) from the study of material human praxis, and aims to transform it. Revolution is not to be understood as the obtention of political power, or solely the change in the economic relations of production, but as the transformation of everyday life.

The publication of the first Critique of everyday life (Lefebvre 1947) in the context of the development of sociology as a leading discipline in post-war France provides the strategic background for Lefebvre's definition of the study of praxis on a sociological basis. But praxis can more broadly and originally be understood as the sum of the practical human relationships to the world and to others in society, or the practices by which human beings define their relationships to nature and their own nature. It is thus open to exploration by a plurality of disciplines. Critical theory aims to find ways by which to raise awareness, to orient and transform praxis. The lefebvrian dialectic sees overcoming as an act that is based on a creative dynamic, a ‘thinking-acting' ( 'une pensée-acte’ Lefebvre 1939b: 58) inspired by his 
reading of Nietzsche's tragedy as the aspiration towards the 'total man' (Lefebvre 1939a). This creative dynamic takes life itself for its central goal and opens new possibilities for lifestyles considered collectively rather than individually. Lefebvre considers art as a way to accomplish the transformation of praxis.

This theoretical background determines the conceptual tools Lefebvre mobilises to study society and argue for the conscious transformation of life. To study praxis is to combine sentient and embodied experiences of daily reality, for example the act of gazing at an agrarian landscape, as described in the first version of the Critique of everyday life (Lefebvre 1947: 141). This experience is then replaced by the shock of the experience of the new town of Mourenx, as described in the Introduction to modernity (Lefebvre 1962), and the transition from rural sociology to urban sociology becomes the focal point of the study of modern man. Yet Lefebvre does not abandon his intellectual project of a theory of praxis. Critical theory is fuelled by its intellectual context and Lefebvre associates himself with avant-garde groups such as the Situationist International, especially Guy Debord, whose relations with Lefebvre were remarkably intense and difficult (Ross 1987; Merrifield 2006). Regardless of the conflict, their exchanges came to inspire a generation of urban theorists, critical of State Planning (Stanek 2011; Le Breton 2012).

Though Bachelard is far removed from critical theory, Lefebvre admires his attempt to reconcile science and poetry, particularly in his Poetics of Space, as he writes in his autobiography La Somme et le Reste (Lefebvre 1959: 142-3). Lefebvre does not just borrow the term "rhythmanalysis" from 
Bachelard, he articulates his own scientific project with a theory of the poetics of the everyday experience as informed by Bachelard. Though critical theory produces empirical studies of urban society, Stanek notes that Lefebvre's bibliography for his courses in urban sociology includes descriptions of cities in philosophy and literature such as those of Heidegger, Sue, Steinbeck, Dos Passos, and Lowry alongside the theoretical writings of planners such as Lynch and Alexander (Stanek 2011: 21). In the second tome of his Critique of everyday life (Lefebvre 1961), Lefebvre defines the principal categories of his sociology and considers a social rhythmology or rhythmanalysis to study the interactions of cyclic and linear periods of time or rhythms.

His enquiry on temporalities is directly linked with his critique of modernity. Cyclic rhythms compose the temporalities of agrarian and traditional societies, in which repetitions of periods in social life are ritualized to become part of symbolic exchanges between life and death, or the cosmic relation of the community to the earth (Lefebvre 1961: 52-4). Lefebvre sees modernity as a process of abstraction (Lefebvre 1962), as it introduces linear temporalities marked by the advent of machines, and above all clocks, representing a time that is fictitiously homogeneous and fragmentable. This measurable time becomes everyday time in accordance with the work time. Lefebvre shows that cyclic rhythms correspond to natural and vital rhythms, and to non-cumulative processes (Lefebvre 1961: Ch. 5). They are predominant in archaic societies (Lefebvre 1961: 318-9), linked to ancient symbols that ritualize social practices, introducing rhythms in order to include individuals in a community. 
In the modern world, where cumulative processes like economic growth are predominant, signs and signals replace older symbols, as Lefebvre claims in his theory of the semantic field (Lefebvre 1961: Ch.4). Because omnipresent signals are conditioning behaviours by means of their linear repetition and participation in the programming of life with all of its satisfactions, linear repetition can bring about monotony, boredom and tiredness. Lefebvre analyses alienation in everyday life in the modern world as a form of this integral programming of time that affects even leisure and rest, to which he opposes enjoyment. Rhythmanalysis is dedicated to the analysis of the persistence of the cyclic rhythms and their interaction with linear rhythms.

Bachelard's rhythmanalysis (Bachelard 1950) is alien to the study of social time. The contemplative philosopher prefers solitary time, free from the requirements of social life. Bachelard focuses on lived time and on how lived instants are dialectically related through rhythms, criticizing Bergson's concept of duration. The temporal 'fortune' and 'efficiency' (Bachelard 1950), arises from the way instants are arranged in rhythmic patterns. Bachelard imagines rhythmanalysis as a personal practice aimed at orientating how energy is spent, especially in thinking activities (learning, memory, creative imagination...) and human relationships. It has a therapeutic or pedagogical goal, completing other practices like psychoanalysis, and responds to the fundamental human need for a temporal dialectic, alternating between full and void. But these temporal practices rely on ever-present social temporalities, isolation being possible in accord with rhythmic social modalities. Thus both can be included in the critique of everyday life as ways of transforming and creating moments. 
Lefebvre did not extend his conception of the production of space to the production of time, but we can imagine that conceiving of social time as a social product would mean thinking the relationship between perceived time, conceived time, and lived time. Rhythmanalysis is presented as a way to study 'concrete modalities of social time' (Lefebvre 2004: 73). Thus Bachelard helps Lefebvre think lived time, allying topo-philia with tempophilia as The poetics of space (Bachelard, 1957) through the consideration of the space of representation, the space we live in, and even 'happy' space. Each society produces their own space and their own time. The question 'How can appropriate time accompany appropriate space' becomes 'How can time be inhabited by a collective lifestyle?' and 'How can rhythmanalysis complete spatio-analysis in the quest for this appropriate space-time?'

\section{Rhythmanalysis and the quest for the appropriation of urban space-time}

By placing rhythmanalysis in the framework of the production of space, Lefebvre articulates it with the appropriation and the abstraction of urban space and time. How do rhythms found the dynamics of the appropriation of space and time? We can assume that these dynamics proceed from the living body, for Lefebvre names the body as the 'constant reference' for rhythmanalysis: 'the theory of rhythms is founded on the experience and the knowledge of the body' (Lefebvre 2004: 67).

Lefebvre evokes the rhythmanalytical project in the chapter 'spatial 
architectonics' (Lefebvre 1974), dedicated to the organic appropriation of space and the creation of forms by means of the material dynamic of the bodily occupation of space. The body plays a crucial role in appropriation dynamics; it secretes its appropriate and qualified space. The body's energy elaborates social space in successive layers and creates the cosmologies that anthropologists study. It is a creative praxis which proceeds from the sensitive and affective relationship of the body to space. Spatial architectonics is also temporal because space and time are inseparable in the living body. Concrete time is made of rhythms that emanate from the body: breathing, heart rate, hunger, walking, sexuality... Marcel Jousse's anthropology of gesture (Jousse 1974) shows that learning is nestled at the heart of a mimetic dynamic specific to human beings, and that gesture impregnates the human body with rhythm. This framework could allow for the micro-sociology of everyday practices, especially in public space, and contributes to the imagination of a spatial and temporal architectonics.

Yet another anthropologist, André Leroi-Gourhan, shows that rhythms contribute to our affective and emotional insertion in the world in Gesture and speech (Leroi-Gourhan 1965). André Leroi-Gourhan does not think that social rhythms are imposed on individuals, but rather created by the activities of living bodies and their relationships with groups and living environments, thus constituting a fabric of aesthetic relationships. Lifestyles are both an emotional and affective insertion into the cosmos and society. He begins with the vital rhythms central to understanding gesture and the creation of human environments, and ends with the creation of symbols of domestic time and space. Days and nights, seasons and walking distances are folded into symbols: rhythms create inhabited space-times. Leroi- 
Gourhan's writings find their echo in Lefebvre's conception of lifestyle and the construction of a corresponding time and space through 'textures' (Lefebvre 1974). Social praxis appropriates rhythms in the creation of social time, and according to the different modalities of specific lifestyles. Situated and acting bodies have inventive capacities that are developed in time, space and through energy.

Lefebvre analyses the modern production of space and time as the concrete production of abstractions (Lefebvre 1974). The urban revolution is the disruption of a cosmic conception of space and time. Cities are no longer inserted into symbolic space and time, they are no longer an image of the cosmos, as was the model of the ancient Greek city. The modern city can no longer be appropriated through old symbols of space and time. This form of abstraction results in a production of repetitive spaces and time that are no longer rhythmic. These modalities transform the aesthetic experience, notably through the predominance of the visual. Bodily rhythms no longer foster the rhythmic appropriation of space and its extension into the creation of a cosmos.

To counter this form of abstraction, Lefebvre proposes rhythmanalysis as the quest to create an appropriate urban space and time. This proposition is correlated to his project for the restitution of the 'total body' (Lefebvre 1974: 465), which would use the knowledge acquired by rhythmanalysis. It can, for example, be found in the therapeutic search for eurhythmia to treat pathologies: 
the living body presents numerous associated rhythms (and we must insist on this crucial point); hence a eurhythmia, when in the state of good health. Pathology, in a word illness, is always accompanied by a disruption of rhythms: arrythmia that goes as far as morbid and then fatal de-synchronisation. (Lefebvre, 2004: 68)

This rhythmic diagnostic can also be used to conceive of urban environments. Because of Lefebvre's pedagogical view of rhythmanalysis as a tool for the appropriation of space (Lefebvre 1974: 237), rhythmanalysis can be thought of as a practical exercise based on listening to rhythms with each bodily sense. It is above all based on the aesthetic experience of rhythms. Furthermore, rhythmanalysis is not only a personal practice, it is a collective practice that is able to transform praxis. Lefebvre is interested in the fact that this creative praxis can create enjoyment. $\mathrm{He}$ develops the relation of the 'total body' to space and time through the perception of rhythms in Toward an architecture of enjoyment (Lefebvre 2014), demonstrating that the creative praxis of appropriation leads to artistic activity, notably in the construction of the urban as a work of art. As we will see, this is what Lefebvre means by poiesis.

Music and dance are 'privileged fields and experimental fields' (Lefebvre 1974: 237; 2004) of the creative experience of rhythms and of lived time. Lefebvre wrote on music and society (Lefebvre 1966; 1971), and meditated on Nietzsche's conception of style as the link between music and lived time (Lefebvre 1970; 1975). The ambivalent relationship between cyclical rhythms related to natural, cosmic, and organic forces, and linear rhythms, related to the measurement and quantification of time, prevails in Lefebvre's 
understanding of musical rhythms. Music appropriates the rhythmic body, as, in Lefebvre's terms:

the relation between musical time and the rhythms of the body is required. Musical time resembles them but reassembles them. It makes a bouquet, a garland from a jumble. Through dance, first of all. Musical time does not cease to have a relation with the physical.

(Lefebvre 2004: 64)

In musical rhythm, the appropriation of time and space occurs through the body, which is why semiology is insufficient in understanding music (Lefebvre 1971). Music gives its texture to the time that is lived in. Following this perspective, Lefebvre equates the conquest of everyday sound in concrete music and underground culture with urbanization and globalization ('mondialisation'). They provide an outlet for tensions in everyday life (Lefebvre 1981: 135). However, the aesthetic experience of the environment is not only a sonic experience. The rhythmic experience of architecture, urban space and landscape leads to an open inquiry (Maldiney 2012; Revol 2015).

The theory of moments marks another attempt on the part of Lefebvre to think appropriate space-time through the idea of repetition. 'Moment' is defined as a superior and richer form of repetition that is created from everyday forms of repetition such as gesture, behavior, instants and disruptions in stable periods of time, objects and artworks, symbols, and affective stereotypes (Lefebvre 1961: 344). Lefebvre describes different 
moments: love, knowledge, games... The 'moment' has temporal qualities of intensity, defined by paroxysmal fullness, and a relationship to duration that Lefebvre qualifies as 'involution' and the accomplishment of a presence (Lefebvre 1961: 345). Lefebvre mystically describes presence as a creative act in La présence et l'absence :

[Presence] supposes and implies an act: the poietic act. This also implies an adherence to being, to the fact of being and to the possibility of a fullness that is never fixed nor fully defined.

Presence, as a moment and not a substance or pure form, rewards the risk-taking act. [author's translation] (Lefebvre 1980: 226)

The 'moment' is what integrates the everyday in order to transform it through the texture of space and time. And though 'moment' does not appear in Lefebvre's texts on rhythmanalysis, the figure of the poet rhythmanalyst is here described, along with the creative activity of this figure as a manner to include rhythms in daily life (Lefebvre 2004: 22-6). This poetic activity transforms everyday life and creates lifestyles comparable with the experimental utopias developed by the avant-garde group, Situationist International.

\section{Rhythmanalysis as experimental utopia}

How can rhythmanalysis be performed as poetic practice? Though Lefebvre did not develop specific descriptions of the poet rhythmanalyst, nor define 
the manner in which urban time and space were to be transformed through this activity, Lefebvre did develop the concept of an 'experimental utopia' in which an understanding of this poetic practice can be found. Utopia as a literary genre proposes to show a society in a spatio-temporal elsewhere in order to criticize the existing order. Lefebvre is inspired by utopian socialists like Charles Fourier, and the conceptualization of concrete utopias by Antonio Gramsci or Ernst Bloch. He considers utopia as a means of transforming reality, and therefore does not dissociate it from critical theory, but rather explores the possibilities of imagining a society that could be created by the Revolution, and fuel the imagination of counter-spaces. It is associated with the creation of an appropriate time-space.

Lefebvre uses the term 'experimental utopia' to describe the practices of the Situationist International that go beyond fictional writings to promote 'a utopia experienced on an experimental basis' (Lefebvre 1961: 336). At the end of the 1950s, the SI defines psychogeography as 'the study of the precise laws and specific effects of the geographic environment, consciously organized or not, on the emotions and behaviours of individuals' (Debord 1955). Its methodology can be found in the experiment of the 'dérive', an urban exploration protocol that consists in a rapid crossing of urban space in the form of a game, thus rendering immaterial frontiers of neighbourhoods and highlighting the attractive and repulsive zones of the city. 'Dérive' is inherited from the literary tradition of the 'flâneur', recalling Balzac, Baudelaire, and the surrealists, including Louis Aragon and André Breton, who are the direct ancestors of the SI groups. Walking without purpose is a way of contesting the reduction of the street to its utilitarian and rational purposes, as well as the practice of 'détournement' (a form of hijacking, or 
of showing another use of an already-employed form or object). It allows for an analysis of the city by means of encounter and chance. The atmospheres of the city were seen as the possibility to construct new situations that would not define art as a specialized activity but include it in the creation of lifestyles. The city as an artwork was to announce the collapse of the society of the spectacle, as Debord would later call it (Debord 1967). The city was to be become an artwork in and of itself, an 'oeuvre'.

Lefebvre sets aside this experimental utopia to develop his critical theory in response to his dispute with Debord in the 1960s. He turns to the theorization of the production of space. Evoking psychogeography in an interview (Ross 1987), Lefebvre considers it as evidence of the fragmentation of the city, meanwhile insisting on the necessity of a broader understanding of the urban phenomenon and urban practices. Moreover, he concedes that psychogeography has been unable to demonstrate any results, and few examples have contributed to the science of atmospheres. Lefebvre is sceptical of the revolutionary potential of the construction of situations, understood as punctual interventions, because the transformation of praxis takes time. The transition from experimental utopia and alternative practices to the right to the city brings forth a far broader program.

Lefebvre imagines the possibilities of an appropriate space-time and the city as an artwork, an 'oeuvre', through the conceptualization of differential space (Lefebvre 1974). Differential space overcomes the abstract space of critical theory through the definition of new centralities, counter-spaces that are appropriated by alternative cultures. They are therefore inseparable from 
utopian lifestyles. Lefebvre is inspired by Fourier's utopian conception of the phalanstery, a unified, collaborative architectural space that is cohesive with human sensibilities. But unlike Fourier's insistence on harmony and lifestyle, which he sees as ascetic, Lefebvre insists on the realization of desire through enjoyment. Lefevrian utopia requires the achievement of a total body, with its excesses and spent energy, as he describes it in Toward an architecture of enjoyment written in 1973 (Lefebvre 2014). In this book, Lefebvre conceives of architectural work as the exploration of a concrete utopia that allows for the exploration of human desires. Utopian architecture here offers a key to differential space, since it imagines the possibility of overcoming the separation between product and oeuvre in a return to nature.

Evoking the rhythmanalyst as 'an enigmatic individual who strolls with his thoughts and his emotions, his impressions and his wonder, through the streets of large Mediterranean towns' (Lefebvre 2004: 87), Lefebvre recalls the practices of his old friends from the Situationist International. If Lefebvre imagines rhythmanalysis as an experimental utopia with creative ambitions, I consider it to be in line with the dérive and psychogeography in specific situations. As with psychogeography, rhythmanalysis requires a sensitive and aware experience involving body displacement or immobility. Rhythmanalysis 'separates as little as possible the scientific from the poetic' (Lefebvre 2004: 87): it has the ambition to constitute a knowledge of concrete space and time through the form of a poetic activity. Its own practice should transform life and its effects.

Because rhythms lie at the heart of architectonics and the appropriation of 
space and time, rhythmanalysis is the experimental practice from which to renew their insertion into the cosmos and create an appropriate space and time in the urban world. Lefebvre seeks an experimental utopia in order to create the urban as an oeuvre.

\section{Rhythmanalysis and Lefebvrian urban poetics}

It is necessary to return to the conceptual framework that Lefebvre developed on modern time to understand how critical theory relates to a poetics. Lefebvre explicit his 'revolutionary romanticism' (Lefebvre 1957; 1962) at the same period in which he builds up his framework for critical theory and produces his first texts on rhythmanalysis. Revolutionary romanticism is anchored in the young Lefebvre's intellectual background, and is the basis from which Lefebvre constructs his personal critique of modern life as he gradually frees himself from the communist party (PCF). The idea of modernity as an abstract process is a romantic one (Lefebvre 1962). The romantic characteristics of this thought lie in its anti-systemic construction, its critique of quantification, mechanisation, and his concern for the dissolution of communities (Löwy and Sayre 1992). To counter modernity's abstraction, Lefebvre defines revolutionary romanticism as a lifestyle and develops his theory of the city as an oeuvre, or artwork of a community. He exchanges with the members of the SI on this set of ideas and elaborates the elements for a poetics of the city.

The result is the definition of the city as an oeuvre in The proclamation of the Paris Commune (Lefebvre 1965a) and The right to the city (Lefebvre 
1968). The implications of these theories are developed in other chapters in this book (see part five and six). It enlightens us on the importance of a certain modality of praxis that Lefebvre call poiesis; the creation of lifestyles as artworks is a central concern among them. Thus Lefebvre's critical theory combines with poetics to open new possibilities for urban society. Theory cannot produce only a critical knowledge of the production of space and time, it must open new horizons for human poiesis.

This conceptualisation of poiesis is completed by the anthropological point of view Lefevre develops in Metaphilosophie (Lefebvre 1965b), where he theorizes more generally the relationship between humanity and its oeuvres. This opens the possibility for the poetic creation of the urban in terms of human artwork (Lefebvre 1965b: 117-8) and the creation of a lifestyle that transforms everyday life. How is rhythmanalysis related to this general program? I assume that rhythmanalysis, by placing lived experience at the basis of experimentation, is the outline for this poetic practice. But it has to be developed as an experimental device rather than an observation methodology.

Lefebvre did not expose rhythmanalysis as a fully elaborated program in his Elements of rhythmanalysis: each practitioner would probably have to find his own way to practice it. But as we have seen, rhythms are essential to the appropriation of space and time, so Lefebvre's rhythmanalysis is engaged to globally rethink the human environment. His aims are related to the objective of building a differential space, in other words to establish an alternative praxis as poiesis. This poiesis is not only focused on the built environment as an architectural project but could encompass the creation of 
new institutions, new rituals, new ways of living, and especially other temporalities...alternatives to neo-liberal urbanization.

\section{Conclusions}

By placing the texts Lefebvre wrote on rhythmanalysis in the general framework of his theory, we have shown that the production of spatial theory is completed by the question of time in the urban era. The rhythmanalytical project thus adds a temporal dimension to the spatial one in its aim to consolidate our quest for the appropriation of time and space. It takes the form of an experimental utopia in which practice is not the application of a theory; it is elaborated exclusively from thinking and acting. This "creative practice", arising from praxis is what we have called poiesis. Thus the rhythmanalytical project invites us to consider the poetic aspects of Lefebvre's thought, and through creative practice, imagine devices to explore the urban as the human oeuvre.

\section{References}

Bachelard, G. (1950) La dialectique de la durée, Paris: Presses Universitaires de France.

- (1957) La poétique de l'espace, Paris : Presses Universitaires de France ; trans. Maria Jolas (1994) The poetics of space, Boston: Beacon Press.

Debord, G. (1955) 'Introduction à une critique de la géographie urbaine', Les Lèvres Nues, 6. 
Debord, G. (1967) La société du spectacle, Paris: Buchet-Chastel.

Jousse, M. (1974) L'Anthropologie du geste, Paris: Gallimard.

Le Breton, É. (2012) Pour une critique de la ville: la sociologie urbaine française, 1950-1980, Rennes: Presses universitaires de Rennes.

Lefebvre, H. (1939a) Nietzsche, Paris: Éditions sociales internationales.

- (1939b) Le Matérialisme dialectique, Paris: F. Alcan ; trans. John

Sturrock (1968) Dialectical Materialism, London : Jonathan Cape.

- (1947) Critique de la vie quotidienne : introduction, Paris: Grasset ; trans.

John Moore (1991) The Critique of Everyday Life, Vol. 1, London : Verso.

- (1957) 'Vers un romantisme révolutionnaire', Nouvelle Revue Française,

1st october $1957: 645-647$.

- (1959) La Somme et le reste, Paris: la Nef de Paris.

- (1961) Critique de la vie quotidienne. 2. Fondements d'une sociologie de la quotidienneté, Paris: l'Arche ; trans. John Moore (2008) Critique of Everyday Life 2. Foundations for a Sociology of the Everyday, London : Verso.

- (1962) Introduction à la modernité : préludes, Paris : Éditions de Minuit ; trans. John Moore (1995) Introduction to Modernity : Twelve Preludes, London : Verso.

- (1965a) La Proclamation de la Commune : 26 mars 1871, Paris:

Gallimard.

- (1965b). Métaphilosophie : prolégomènes, Paris: Les éditions de Minuit.

- (1966) Le Langage et la société, Paris: Gallimard.

- (1968) Le Droit à la ville, Paris: Anthropos.

- (1970) La Fin de l'histoire : épilégomènes, Paris: Éditions de Minuit.

- (1971) 'Musique et sémiologie' Musique en jeu, 4 : 52-62.

- (1974) La production de l'espace, Paris: Anthropos ; trans. Donald Nicholson-Smith (1991) The Production of Space, Malden : Blackwell. - (1975) Hegel, Marx, Nietzsche ou le Royaume des ombres, Paris:

Casterman.

- (1980) La présence et l'absence: contribution à la théorie des 
représentations, Paris :Casterman.

- (1981) Critique de la vie quotidienne 3. De la modernité au modernisme, Paris: l'Arche ; trans. John Moore (2005) Critique of Everyday Life 3. From Modernity to Modernism, London : Verso.

- (1992) Éléments de rythmanalyse. Introduction à la connaissance des rythmes, Paris : Éditions Syllepses.

Lefebvre, H. and Elden, S. (eds) (2004) Rhythmanalysis: Space, Time and Everyday Life, London : Continuum.

Lefebvre, H. and Guterman, N. (1936) La conscience mystifiée, Paris: Gallimard.

Lefebvre, H. and Guterman, N. 'Introduction' in V.I. Lénine, (1938)

Cahiers sur la dialectique de Hegel, Paris: Gallimard.

Lefebvre, H. and Régulier, C. (1985) 'Le projet rythmanalytique', Communications, 41(1):191-9.

Lefebvre, H. and Régulier, C. (1986) 'essai de rythmanalyse des villes méditerranéennes', Peuples Méditerranéens, 37.

Lefebvre, H. and Stanek, Ł. (eds) (2014). Toward an architecture of enjoyment, Minneapolis : University of Minesota Press.

Leroi-Gourhan, A. (1965) Le geste et la parole. La mémoire et les rythmes, Paris: Albin Michel ; trans. Anna Bostock Berger (1993), London : The MIT Press.

Löwy, M. and Sayre, R. (1992) Révolte et mélancolie: le romantisme à contre-courant de la modernité, Paris: Payot.

Maldiney, H. (2012) Regard, parole, espace, Paris: Édition du Cerf. Merrifield, A. (2006) Henri Lefebvre: A Critical Introduction, London, Routledge.

Revol, C. (2015) La rythmanalyse chez Henri Lefebvre (1901-1991): contribution à une poétique urbaine, unpublished thesis, Université Lyon 3. Ross, K. (1987) 'An interview with Henri Lefebvre', Society and space, 5(1): $27-38$.

Stanek, L. (2011) Henri Lefebvre on Space: Architecture, Urban Research, 
and the Production of Theory, Minneapolis: University of Minnesota Press. 